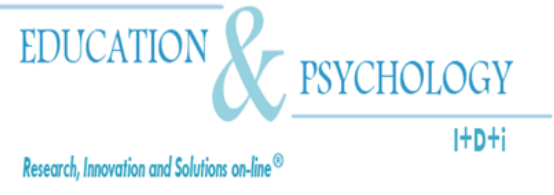

\title{
Mathematics Primary Teacher Training at the University of Granada: an Adaptation to the EHEA
}

\section{Francisco Ruiz, Marta Molina, Jose Luis Lupiáñez, Isidoro Segovia and Pablo Flores}

Department of Didactics of Mathematics, University of Granada

\section{Spain}

Dirección Postal: Facultad de Ciencias de la Educación, Departamento Didáctica de la Matemática, Universidad de Granada. Campus de Cartuja. 18071 Granada (España). E-mail: fcoruiz@ugr.es 


\begin{abstract}
The future implementation of the European Higher Education Area (EHEA) requires thorough reflection on how to design and develop teacher training courses. In this reflection, it is important to reconsider, among other issues, the role of prospective teachers in their own learning process and the professional competences that they must develop in the course of their higher education. Since 2004, the University of Granada has undertaken the development of pilot experiences to adapt some degree programs to this new framework, within them the degree Teacher in Primary Education. This degree includes several courses for promoting prospective teachers' development of mathematical and pedagogical knowledge. In this paper we first analyse the general process of adapting these courses. Secondly we describe its theoretical and practical structure, with some examples of practical activities related to arithmetic and number sense. Finally, some results of the implementation are discussed.
\end{abstract}

As a response to the challenge set out in the Bologna Declaration ${ }^{1}$, since 2001 over 175 European Universities had worked intensively to create the European Higher Education Area (EHEA). This project is not only European. In 2004, when the Latin American Tuning Project was created, many latinamerican universities joined this deep reflexion about higher education guided by commom interests such as (a) promoting the compatibility, comparability and competitiveness in higher education, and (b) tailoring programs to the needs of society at both local and global levels (Beneitone, Esquetini, González, Maletá, Siufi and Wagenaar, 2007).

Within this context, here we describes an innovative experience in the effort to adapt mathematics education training for prospective primary school teachers to the new directives proposed, within the current Spanish legal framework. We explain the adaptation process and the results obtained within a pilot experience developed in the Department of Mathematics Education at the University of Granada.

Keywords: European Higher Education Area, Primary Education, Teachers' training, Mathematics Education.

Received: 12/15/08 Initial Acceptance: 01/29/09 Final Acceptance: 02/23/09

\footnotetext{
${ }^{1}$ http://www.ond.vlaanderen.be/hogeronderwijs/bologna/ 


\section{Resumen}

La futura implementación del Espacio Europeo de Educación Superior (EEES) requiere reflexión sobre la forma de diseñar y desarrollar cursos de formación del profesorado. En esta reflexión, es importante reconsiderar, entre otras cuestiones, el papel de los futuros profesores en su propio proceso de aprendizaje y las competencias profesionales que deben desarrollar en su educación superior. Desde 2004, la Universidad de Granada ha llevado a cabo el desarrollo de experiencias piloto para adaptarse en cierta medida a los programas de este nuevo marco, entre el que se encuentra el grado de Maestro de Educación Primaria. Este grado incluye varios cursos para promover el desarrollo del conocimiento matemático y didáctico de los futuros maestros. En este trabajo analizamos en primer lugar el proceso general de adaptación de dichos cursos. En segundo lugar, describimos su estructura teórica y práctica, con algunos ejemplos de actividades prácticas relacionadas con la Aritmética y el sentido numérico. Finalmente, se discuten algunos resultados de la implementación. Como respuesta al reto que supone la Declaración de Bolonia, desde 2001, más de 175 universidades europeas han trabajado intensamente para crear el Espacio Europeo de Educación Superior (EEES). Este proyecto no sólo es europeo. En 2004, cuando se creó el proyecto latino americano Tuning, muchas universidades latinoamericanas se sumaron a esta reflexión sobre la educación superior guiada por intereses comunes, tales como (a) promocionar la compatibilidad, comparabilidad y competitividad en la educación superior, y (b) adaptar los programas a la necesidades de la sociedad tanto en el ámbito local como global (Beneitone, Esquetini, González, Maleta, y la Siufi Wagenaar, 2007). Dentro de este contexto, describimos aquí una experiencia innovadora en el esfuerzo por adaptar la formación en Educación Matemática de los futuros maestros de primaria a las nuevas directivas propuestas, dentro del actual marco jurídico español. Exponemos el proceso de adaptación y los resultados obtenidos en una experiencia piloto desarrollada en el Departamento de Didáctica de la Matemática de la Universidad de Granada.

Palabras clave: Espacio europeo de educación superior, formación, profesorado, Educación Primaria, Matemáticas

Recibido: 15/12/08 Aceptación inicial: 29/01/09 Aceptación final: 23/02/09 


\section{Changes towards the EHEA}

The ultimate goal of the EHEA is to have universities adopt a system of degree programs that will be comprehensible and comparable in all European Union countries by 2010. Some of the directives established have been given concrete form in Spain in laws governing the development of the future degrees. One of these is the so-called "European credit" or ECTS (European Credit Transfer System) credit, which involves a change in the way of measuring student workload. Another consists of characterizing each degree in terms of the general and professional competences that define the degree-holder's professional profile. These two directives require a substantial change in the teaching activity. They focus on the student and conceive the professor's role as that of a guide and an advisor to ensure that students acquire the established competences.

In embracing these directives, since 2004 the Andalusian Regional Government has promoted experimentation with current university degree programs to draw conclusions from the experience that will enable the design of new degrees in accordance with the EHEA. Forteen degree programs have been chosen for undertaking this experimentation, among them the degree Teacher in Primary Education.

One of the research interests of the research group in Number Thinking of the Junta de Andalucía (FQM193) is primary and secondary mathematics preservice and in-service teachers' training. The members of the Department of Mathematical Education of the University of Granada who work in this group have participated in the innovative experimentation that is described in this article.

\section{Primary Teachers' training in Mathematics and Mathematics Education at the Univer- sity of Granada}

In the degree Teacher in Primary Education at the University of Granada, there are two Mathematics Education courses: Mathematics and its Pedagogy (a core course of 4.5 theoretical and 4.5 practical credits) and The Mathematics Curriculum in Primary Education (a compulsory course of 2 theoretical and 2.5 practical credits). Students can complete their training by choosing between other several mathematics education elective courses. 
The core first-year course mentioned above is designed to ground the students' mathematical knowledge. It aims to deepen the mathematics skills that they developed during their required secondary schooling, before introducing new concepts in Mathematics Education. The term we used to designate this option is: Mathematics for teachers. In this course the contents are mathematical, involving the concepts and procedures, their representations, phenomenology, modelling and history (Rico, 1997). The scope of these concepts and their area of formalization, application, signification, representation and study, corresponding to those a Primary Education teacher should have. Mathematics is presented from a cultural, social and epistemological perspective consistent with the current official curricula for this education level.

The compulsory course, indicated for the second year, seeks to professionalize the future teacher in his or her role as math educator and thus requires that he or she masters certain concepts in Mathematics Education. These concepts are always channelled to facilitate the comprehension of the curriculum, as well as the design, implementation and evaluation of the teaching of Mathematics in Primary Education.

\section{The Pilot Experience in the Course "Mathematics and its Pedagogy"}

Now we focus on the innovative experience developed in the course "Mathematics and its Pedagogy". We began the experimentation with the European model during the academic year 2004-2005.

This experience became the focus of greatest reflection and attention in the Department's teaching seminars. In confronting this course, in addition to adapting the program numerically to the ECTS and redefining the objectives to adapt them to competences, it was found important to establish a precise differentiation between theoretical and practical credits.

Diverse variables utilised managed to distinguish the theory and the practice. Ferrater (1991, p. 2652, 2661) shows different ways to understand these variables, both in training processes in general and in teacher training. These differences were grouped into two blocks: 
the first corresponding to the epistemological separation between theoretical and practice knowledge and the second to the competences and thus the way of teaching.

The division between the theoretical and practical credits in the courses is based on the actions performed during teaching and the competences that the students are to acquire. One way of viewing the practical credits in this context is to focus on tasks in which the theoretical concepts are applied to solve problems in the professional world (professional practices, such as class planning, the design and qualification of exams, etc.) or in the everyday world (mathematical practices for solving problems, analysing phenomena, interpreting information, etc.). Another perspective is that work for the practical credits must tackle procedural competences tied to know-how, such as those related to the use of technological means for teaching (professional practice) or the use of mathematical procedures (mathematical practice) (Monereo, 1994, Pozo and Monereo, 1999).

Finally, but not unrelated to the foregoing aspects, another differentiation between theory and practice can be made based on the degree to which students acquires a leading role in the performance of tasks. This idea enables us to consider as practical activities those in which students act. The idea of practice would thus be tied not to the content encountered but to the way this content is related to knowledge. A theoretical, conceptual content can be considered in a practical way if we give students a leading role in performing activities that enable them to interpret it, debate it with classmates, share it with others, present it, and contrast it with texts in which it is defined, characterized, exemplified, etc. Thus, practice is understood like Resnick and Ford (1981), as exercise.

In the organization of the course, we have adopted this last criterion to distinguish the practical credits. The teaching has been organized by differentiating the theoretical classes from the practical classes according to the kind of action undertaken by the teacher and the students, not by the content proposed. This criterion agrees more closely with some of the basic ideas for change under debate, which are directed to emphasizing that students assume a greater role in their learning.

One of the most important innovations involved in the future new curricula adapted to the EHEA is planning objectives as professional competences to be acquired. We have elaborated a unified list of professional mathematical competences for teachers (Appendix A) after 
discussions about the following four list of competences: (1) competences for primary teachers from the ANECA (Spanish Nacional Agency of Quality and Qualitication Evaluation); (2) competences for primary teachers agreed on Andalusia for the ECTS experimentation, (3) competentes extracted from the Tuning project; and (4) competentes for primary teachers by Pollard (1997).

The teaching load for the course involves 3 hours a week throughout the academic year which are divided into one session of two hours and another of one hour, with the following time organization:

- Theoretical credits: Two hours of class a week for 21-weeks of the academic year, orientation seminar of one hour a week for 21 weeks, and individualized tutorials during the professor's office hours throughout the year.

- Practical credits: Practical action seminars for the students for three hours in the course of seven weeks, each one at the end of each lesson.

We have designed and developed some guidelines to coordinate the teachers' performance on both theoretical and practical credits. These guidelines include specific objectives and competences that we want to achieve in future teachers as well as methodology and assessment guidances. The elaboration and discussion of these guidelines have allowed us to share information about how we consider mathematical and didactical knowledge and different methodological strategies. In following sections we describe these guidelines.

The contents of the course Mathematics and its Pedagogy for primary teachers include both mathematical content of primary school and some aspects related to their learning and teaching. It is organized around seven lessons: three about arithmetic, two about geometry, one about measurement and another about probability and statistics.

Arithmetic is a very important component of mathematics in primary school. In fact, arithmetic represents about the $50 \%$ of the syllabuses in differents levels (MEC, 2007). Therefore, arithmetic must be also a main component in the primary preservice teachers' training. That is why almost half of the course is focused on this part of school mathematics.

Future primary teachers manage with natural numbers and their operations fluently. Then, in this course, the contents are focused on the meaning of these numbers and operations but putting special interest in pedagogical content knowledge (Shulman, 1986). As these pro- 
spective primary teachers have mathematical knowledge, the main goal is that they understand and manage the principles of the Decimal Number System, the properties of four basic operations, their standards algorithms and the identification of problems which are related with these operations. We dedicate a big amount of time to work with future teachers on these aspects and their relations. In addition, in the course students also analise the social and educational role of natural numbers, and they explore didactical resources to be used to promote and improve primary students'arithmetic learning.

Most of these components of arithmetic are strongly connected to the idea of number sense which can be defined as a good intuition about numbers and their relations which includes, within other components, understanding the different meanings of numbers, recognizing their relative magnitude, understanding positional value and the part-whole relationship and flexibly choosing between computation strategies (Reys et al., 1980; Sowder, 1992). Within our approach to the arithmetic contents addressed in the course, we remark the importance of number sense by contrasting it to the rote learning and mechanical application of procedures. Along the course we try to help students develop their number sense as well as to promote their competence to identify the elements of which it is composed and ways in which it can be elicited in arithmetic teaching. Number sense is an essential ability for prospective teachers in order to be able to flexibly approach the teaching of arithmetic and understand their students' numerical thinking.

\section{The theoretical credits}

In the theoretical class sessions, the teaching responsibility is the professor's. The professor provide material so that students can undertake the study of the course in a significant way, without this involving the presentation of all contents and results that students must learn. To achieve this, the professor performs tasks like those students are expected to perform, making explicit the actions involved; students observe in order to construct a conceptual model of these tasks (modelling) or the teacher carries out part of the task and encourages the students to perform other parts with the professor's help (scaffolding) (Vizcarro, Liébana, Hernández, Juárez and Izquierdo, 1999). 
These teaching processes consider the contents holistically (Moral, 2001), leaving the specific parts for the students to perform with the support of the recommended documents. This method seeks to produce deep learning of the concepts covered by developing them with growing complexity and diversity and global abilities (Vizcarro et al., 1999). During the development of the theoretical contents, the practices of contextualization, application and evaluation are performed (Díaz-Godino, 2005) through the methods of instruction indicated.

The orientation seminars take place every week for an hour. In these sessions, the students must express their needs, questions, etc. The activities requested by the students are also performed; activities related to those developed previously by the professors and inspired by the questions that will later be used in the evaluation tests. To this end, students are encouraged to perform the proposed tasks, from the interpretation of the data to the search for necessary information, while the professor provides the information requested (training). In other cases, students choose the tasks to solve and demonstrate their abilities by reasoning and interpreting the concepts employed in solving them (articulation).

Finally, the tutorials provide individualized attention in the professor's office, resolving difficulties that students encounter with the topics covered in the course and the tasks required of them. During these tutorials, the instruction provided is based on training, scaffolding, modelling and reflection. In order to direct the action, we have developed some lesson guides that orient students and guide the professor's work in class. Students perform the assigned tasks, working in groups or individually, participate in presentations, and develop and present the work developed using the appropriate technological media.

As an example we present in Appendix B the guide for the first lesson about Natural Numbers. This lesson is focused on the Decimal Number System. We expect students to:

- reflect about the concept of natural number,

- make a distinction between the concept of natural number and the sign that we use to represent it,

- know and manage counting and ordering principles,

- recognize different uses of natural numbers, and

- understand and appreciate the principles of the Decimal Number System (DNS). 
The following tables show in which competences listed in Appendix A2 our design for the first lesson is focused on. We use one asterisk to express a low contribution, two asterisks to express a medium contribution and finally three asterisks to express a high contribution.

Table 1. Contribution of the first lesson to specific mathematics competences

\begin{tabular}{|c|c|c|}
\hline \multicolumn{2}{|c|}{ Competence } & \multirow{2}{*}{$\begin{array}{l}\text { Contribution } \\
* * *\end{array}$} \\
\hline 1.1 .1 & $\begin{array}{l}\text { To know and understand the mathematics contents of } \\
\text { Primary School Curriculum }\end{array}$ & \\
\hline 1.1 .2 & $\begin{array}{l}\text { To know and understand foundations and history of } \\
\text { mathematics of didactic interest in relation to the Primary } \\
\text { School Curriculum }\end{array}$ & $* *$ \\
\hline 1.1 .3 & $\begin{array}{l}\text { To know and understand the social and cultural role of } \\
\text { mathematical contents of the Primary School Curriculum }\end{array}$ & $* * *$ \\
\hline 1.2 .3 & $\begin{array}{l}\text { To know and to assess critically the contributions of } \\
\text { Mathematics Education to the teaching and learning of } \\
\text { mathematical contents and processes addressed in pri- } \\
\text { mary education, and referred to curricular guidelines, } \\
\text { stages of learning, kind of errors and difficulties, assess- } \\
\text { ment tools, experienced proposals of education, etc. }\end{array}$ & $* * *$ \\
\hline 1.2 .4 & $\begin{array}{l}\text { To know about the different forms of organization of a } \\
\text { classroom that can be used in mathematics, recognizing } \\
\text { the specificities of the area of mathematics }\end{array}$ & $* * *$ \\
\hline 1.2 .7 & $\begin{array}{l}\text { To use the processes of mathematical symbolization and } \\
\text { representation (verbal, numerical, symbolic, geometric, } \\
\text { graphical...). }\end{array}$ & $* * *$ \\
\hline 1.2 .8 & To translate from one into another kind of representation & $* * *$ \\
\hline 1.2 .9 & $\begin{array}{l}\text { To coherently communicate basic mathematics in a spo- } \\
\text { ken and written way }\end{array}$ & $* * *$ \\
\hline 1.2 .10 & $\begin{array}{l}\text { To understand, to interpret and to judge mathematical } \\
\text { ideas presented in a written, oral or visual way }\end{array}$ & $* * *$ \\
\hline 1.2 .11 & $\begin{array}{l}\text { To identify and generate examples of concepts in differ- } \\
\text { ent contexts and situations }\end{array}$ & $*$ \\
\hline 1.2 .12 & $\begin{array}{l}\text { To recognize the various meanings and interpretations of } \\
\text { the concepts }\end{array}$ & $* * *$ \\
\hline 1.2 .13 & To recognize and define concepts and their properties & $* * *$ \\
\hline 1.2 .14 & $\begin{array}{l}\text { To recognize the relational elements of a conceptual } \\
\text { structure }\end{array}$ & $* *$ \\
\hline 1.2 .16 & To explain the different steps of a procedure & $* * *$ \\
\hline 1.2 .20 & $\begin{array}{l}\text { To provide arguments to justify answers to mathematical } \\
\text { questions and procedures }\end{array}$ & $* * *$ \\
\hline 1.2 .21 & To use the various ways of mathematical reasoning (in- & $* *$ \\
\hline
\end{tabular}

\footnotetext{
${ }^{2}$ This list of competences was elaborated in the project UGR 041 of UCUA: Design, implementation and assessment of practice contents in Mathematics Primary Teachers Training
} 


\begin{tabular}{ll}
\hline \multicolumn{3}{c}{$\begin{array}{l}\text { ductive, proportional, spatial and deductive) to justify } \\
\text { properties and procedures }\end{array}$} \\
\hline $1.2 .22 \begin{array}{l}\text { To show skill in using materials and resources for ele- } \\
\text { mentary mathematics, including ICT }\end{array}$ \\
\hline 1.3 .1 & $\begin{array}{l}\text { To have a positive disposition and attitude toward } \\
\text { mathematics, valuing it social and cultural role }\end{array}$ \\
\hline 1.3 .2 & $\begin{array}{l}\text { To recognize the role of mathematics as a language, as a } \\
\text { tool for solving problems and as a tool for modelling the } \\
\text { reality }\end{array}$ \\
\hline
\end{tabular}

Table 2. Contribution of the first lesson to professional competences to teach Mathematics in Primary School

\begin{tabular}{|c|c|c|}
\hline \multicolumn{2}{|c|}{ Competence } & Contribution \\
\hline \multirow[t]{4}{*}{2.1 .1} & $\begin{array}{l}\text { To know and to evaluate critically theoretical founda- } \\
\text { tions of the Mathematics Education, applied to primary } \\
\text { education levels, with regard to: }\end{array}$ & \\
\hline & 2.1.1a Educational perspective of mathematics & * \\
\hline & 2.1.1c Mathematical curriculum in primary education & * \\
\hline & $\begin{array}{l}\text { 2.1.1d Technological resources and manipulative materi- } \\
\text { als }\end{array}$ & $* * *$ \\
\hline 2.1 .2 & $\begin{array}{l}\text { To know media, materials and resources usual in the } \\
\text { teaching and learning of mathematics, including } \mathrm{ICT}^{3}\end{array}$ & $* * *$ \\
\hline 2.1 .3 & $\begin{array}{l}\text { To know and to assess critically the contributions of } \\
\text { Mathematics Education to the teaching and learning of } \\
\text { mathematical contents and processes addressed in pri- } \\
\text { mary education, and referred to curricular guidelines, } \\
\text { stages of learning, kind of errors and difficulties, assess- } \\
\text { ment tools, experienced proposals of education, etc. }\end{array}$ & $*$ \\
\hline
\end{tabular}

Table 3. Contribution of the first lesson to professional competences (interdisciplinary)

\begin{tabular}{lll}
\hline Competence & Contribution \\
\hline 3.1 .2 & $\begin{array}{l}\text { To use research, proposal and problem-solving strategies } \\
\text { both in school and non-school situations }\end{array}$ & $* *$ \\
\hline 3.1 .6 & $\begin{array}{l}\text { To be able to learn autonomously in order to facilitate } \\
\text { their professional update in a future }\end{array}$ & $* *$ \\
\hline 3.4 .3 & $\begin{array}{l}\text { Commitment to work and to those people connected } \\
\text { through work }\end{array}$ & $* *$ \\
\hline
\end{tabular}

\footnotetext{
${ }^{3}$ Information and Communication Technologies
} 
Table 4. Contribution of the first lesson to transversal or interdisciplinary competences

\begin{tabular}{lll}
\hline \multicolumn{2}{l}{ Competence } & Contribution \\
\hline 4.1 .1 & Capacity for analysis and synthesis & $* *$ \\
\hline 4.1 .2 & Capacity to organize and to plan & $* *$ \\
\hline 4.1 .3 & Basic general knowledge in the field of study & $* * *$ \\
\hline 4.1 .4 & Basic knowledge of the profession in practice & $* * *$ \\
\hline 4.1 .5 & Oral and written communication in their native language & $* * *$ \\
\hline 4.1 .7 & Elementary computing skills & $* * *$ \\
\hline 4.1 .8 & Management of information skills & $* * *$ \\
\hline 4.1 .9 & Problem solving & $* * *$ \\
\hline 4.1 .10 & Decision-making & $* *$ \\
\hline 4.2 .1 & Critical and self-critical abilities & $* *$ \\
\hline 4.2 .2 & Teamwork & $* * *$ \\
\hline 4.2 .8 & Ethical commitment & $* *$ \\
\hline 4.3 .1 & Capacity for applying knowledge in practice & $* * *$ \\
\hline 4.3 .2 & Research skills & $* *$ \\
\hline 4.3 .3 & Capacity to learn & $* * *$ \\
\hline 4.3 .4 & Capacity to adapt to new situations & $* *$ \\
\hline 4.3 .5 & Capacity for generating new ideas (creativity) & $* *$ \\
\hline 4.3 .8 & Ability to work autonomously & $* * *$ \\
\hline 4.3 .11 & Concern for quality & $* * *$ \\
\hline 4.3 .12 & Will to succeed & $* * *$ \\
\hline
\end{tabular}

Next, we describe how some of these contributions are expressed in the activities of the first lesson.

Competence 1.1.2 is related to mathematics history, and in the activities of the lesson prospective teachers deal with the development of different number systems and their transformation into the present decimal number system.

Competences 1.2.1 to 1.2.6 are related to problem solving and is this lesson we include problems about ordering and counting in different situations in which these problems could be used.

Competences 1.2.7 and 1.2.8 are related to representation systems, which is one of the more important aspects in arithmetic lessons. The distinction between numeral and its sign, the use of symbolic characters, the importance of representation in decimal number system and in others number systems or the use of number line and a hundred-chart are the main as- 
pects that we include in the activities. In addition, previous aspects also contribute to competences 1.2.9 and 1.2.10 from a communicative point of view.

Competences 1.2.11 to 1.2.14 are related to conceptual structure, which takes a very important place in this lesson because numbers and their representations are basic in mathematics. However, competences from 1.2.15 to 1.2.21 are related to procedures which are less important in this lesson.

Competences 2.1.1 and 2.1.2 are related to knowledge of learning' resources. Many activities of the lesson that we are describing are focused on that future teachers manage with different resources like horizontal and vertical abacus, multibase blocks, calculator or electronic resources4.

In relation to transversal or interdisciplinary competences, the most important in this lesson are those that are related to learn to learn, because the design of the lesson is oriented toward the student' autonomy, according to the EHEA.

For promoting the development of all these competences, in theoretical credits we emphasize the distinction between a number and their representations in order to clarify the number' notion. We also introduce numbers through their uses in different situations and contexts. Then, we present another two important aspects: ordering and quantifying. The last part of the lesson is focused on the decimal number system and its principles, and on their importance in school mathematicas as well.

\section{The practical credits}

In the practical class sessions, students are the ones who perform the tasks that the professor has planned. In these sessions the tasks consist of problems of exercitation, application and evaluation (Díaz-Godino, 2005); or experiences, illustrative experiments, practical exercises and research (Caamaño, 2003). All of these include activities of observation, prediction, critique, generation and analysis (Llinares, 1998). The work model proposed covers reading

\footnotetext{
${ }^{4}$ Most of these electronic resources are avalaible from http://illuminations.nctm.org and http://nlvm.usu.edu/ Web sites.
} 
the guide document, carrying out group work with the material provided, presenting results and completing a team workbook. In the course of the class, we perform the following models of instruction:

- Training: Students perform tasks, while the professor observes this performance and gives advice and help.

- Articulation: Students resolve tasks, demonstrating their reasoning and abilities.

- Reflection: Students compare their processes for solving problems with those of their classmates, first through group work and then by means of performing presentations and discussions.

- Exploration: Students develop new situations to which to apply the concepts learned. In designing the tasks they propose, they are encouraged to find new situations affected by the concepts learned.

Practical activities, in which the students act on concrete material under the professor's supervision, are also stimulated.

To achieve this, students are divided into two subgroups for their practical classes. These groups rotate through two different weekly scenarios: the math laboratory (manipulative materials) and the computer lab. Two professors supervise the practical classes, each one in a specific scenario.

In each subgroup, the students work in teams of four, remaining in the same small group for the whole academic year. Likewise, the same professor who directs the practice activity in a particular scenario supervises the two blocks of content for which they perform the practical classes in that scenario. We plan tutorials directed to meet with the teams several times throughout the course, such that each team has at least one tutorial with one of the professors for the practical tutorials.

The work in practical credits requires students to act, first as individuals and then as a team. The professor presents the activities, responds to questions, encourages the students in their work, promotes students' exchange of ideas and coordinates a final whole group discussion in the last half an hour of the two hours sessions. This requires the use of "practical workbook guides" (Flores and Segovia, 2004; Molina and Roa, 2008) with the relevant instructions and activities. 
As an example we now develop on the practice work corresponding to the first lesson of the course. As previously explained, we have designed practical work for two different scenarios: computer lab and the mathematical lab (manipulatives materials). The aim of the practical work of this lesson is to help students distinguish between the concept of natural number and the sign that we use to represent it, become aware of the existence of many different ways to represent numbers, and understand the principles of the DNS.

This translates into promoting the development of the following competences:

1.1.1. \& 1.2.6. To know and understand the mathematics contents of Primary School Curriculum (Concept of number and its representation, caracteristics of the DNS) and to be able to apply them in practical situations

1.2.3., 1.2.12. \& 1.2.10. To understand and to interpretate mathematical ideas and problems which are relevant in mathematics teaching (here mainly those related to the conceptual difficulty of the concept of number and its representations).

1.2.20. To provide arguments to justify answers to mathematical questions and procedures (here specifically to justify their partners their observations about the considered number systems and the procedures to change of base.

4.3.3. To improve/develop their capacity to learn stimulated by the use of material which serve as obtain mathematical procedures (as those used to change between the expression of numbers in different bases by grouping according to the different order units or by using base blocks).

The students have to work with virtual and manipulative materials (abacus and multibase blocks) and are asked to represent quantities by using different systems (DNS, Roman number system, multibase blocks, vertical and horizontal abacus). They are guided in the analysis of these different representations systems, and specially or the Decimal Number System. We specially highlight the signs and principles of the DNS: additive, multiplicative, positional, base 10 and need of zero. Through the transformation of base blocks students give meaning to the change of base.

We have been careful in the design of these activities with distinguishing between quantifying and counting. The former includes the later but also other quantifying strategies such as perception (subitization), or grouping according to the different order units (units, 
tens, hundreds,...). Counting is proposed to make students work with the numerical sequences in different bases: in its expression in the DNS as well as in the specific material at hand.

\section{Practical workbook guides}

The workbooks for the practical sessions are designed to foster autonomous work in our students (prospective teachers), while also constituting one of the indicators for evaluation of their performance.

There are individual and team workbooks, classified according to the six lessons of the course and into two practical scenarios (Manipulative Materials, and Computers lab) for a total of 14 workbooks. Each student has an individual workbook, which includes the explanations, activities, resources and documented sources to enable the student to tackle each of the practical activities. The team workbook unifies the work performed individually and includes additional reflection activities on the earlier individual work.

To illustrate the contents and structure of the practical workbooks, we now present some examples. Each example corresponds to one of the scenarios and describes just one of the activities included in a workbook (the text is directed to the students).

\section{Example 1: Practical workbook for working in the Math laboratory (manipulative materi- als). Activity: Operating with the Abacus}

The abacus is a tool that is used for centuries to perform calculations. Until the fifteenth century numbers operations were performed with the abacus, and even now this instrument is still used in some countries as a pocket calculator. The spread of positional numbering system, making use of zero, along with the invention of paper, were decisive in replacing the use of the abacus by the use of the pencil and paper algorithms that we use today.

This activity suggests calculations to perform with the abacus directed to identify rules that govern the use of this instrument. Our main intention with this activity is to help you to consolidate your knowledge of the properties of the numbering system and the computational algorithms. The specific objectivies of this activity are: 
a) To know about the types of abaci and their use.

b) To recognize the properties of positional numbering system from the use of abacus: recognition of the principle of grouping, notion of value position of the figures, decomposition of a number in powers of 10 .

c) To understand the mechanism of algorithms through the manipulation of calculations on the abacus

d) To transfer the manipulative representation through the abacus to the written representation used in the pen and paper algorithms and vice versa.

e) To explore relationships and properties of natural numbers through representations using the abacus

\section{General description of the exercise}

In this activity a summary of different types of abaci are provided to the students (Roman, Chinese, Japanese, Russian) and the difference between the horizontal and vertical abacus is highlighted. Students are asked to use these two types of abaci to perform representations of numbers and arithmetical operations, indicating the appropriate steps to solve such operations.

By way of example we show two of these activities concerning to the sum of natural numbers using the horizontal abacus.

Use the horizontal abacus to carry out the following additions:

$$
65+28=\quad ; 81+46=; 387+575=\quad ; 3572+5849=
$$

Make a representation of the suitable steps for the addition $387+575=$. Since the numbers are greater than hundreds, two abaci (one for units and the other for hundreds) are needed in order to represent these operations. 


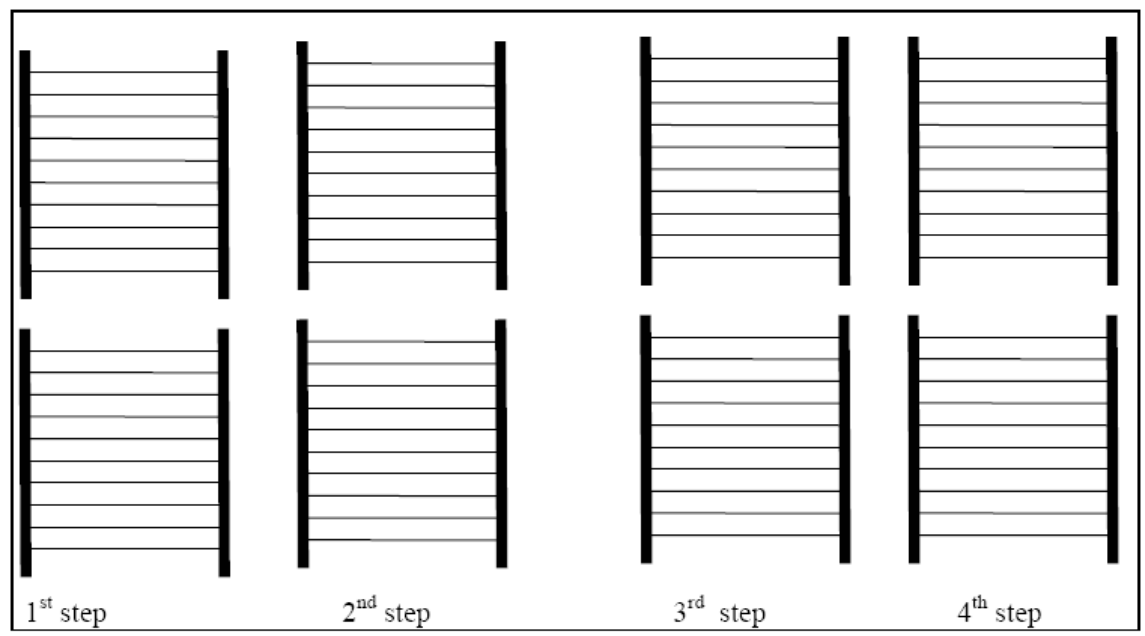

Represent in a table as shown on the right the transformations that you made in each operation of the previous task. In order to do it, write the necessary changes made to the first addend to obtain the result. Carry out the operations and note them in the table more

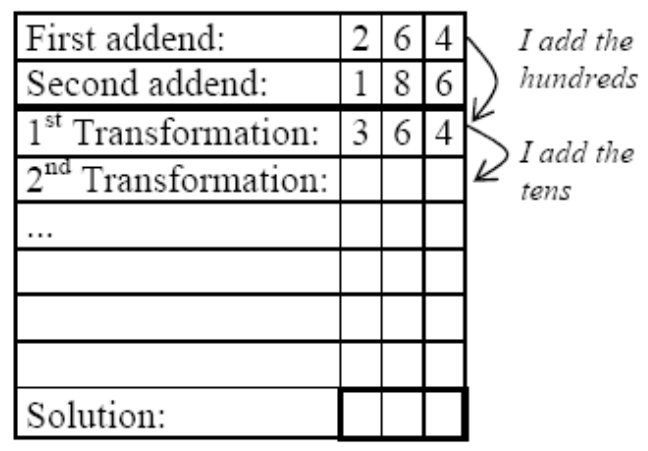
than once, starting with a different order of units each time.

Example: $264+186$.

\section{Example 2: Practical Workbook for working in the Computers Lab. Activity: Adding Base Blocks}

In the following Web page, you could find an applet relating to represent and solve sums in different bases.

http://nlvm.usu.edu/es/nav/frames_asid_154_g_3_t_1.html

This applet consists of individual units, longs, flats, and blocks, in different bases, which are organized into columns. They can be used to show place value for numbers and to increase understanding of addition. You may drag a base block into a column to the left or back to its appropriate column, but when you move a block one column to the right, it breaks apart to show that you have made an exchange. To group pieces to make an exchange the other direction, click and hold the mouse key down while dragging a rectangle to join the pieces. The newly grouped object can then be dragged into the next column. 


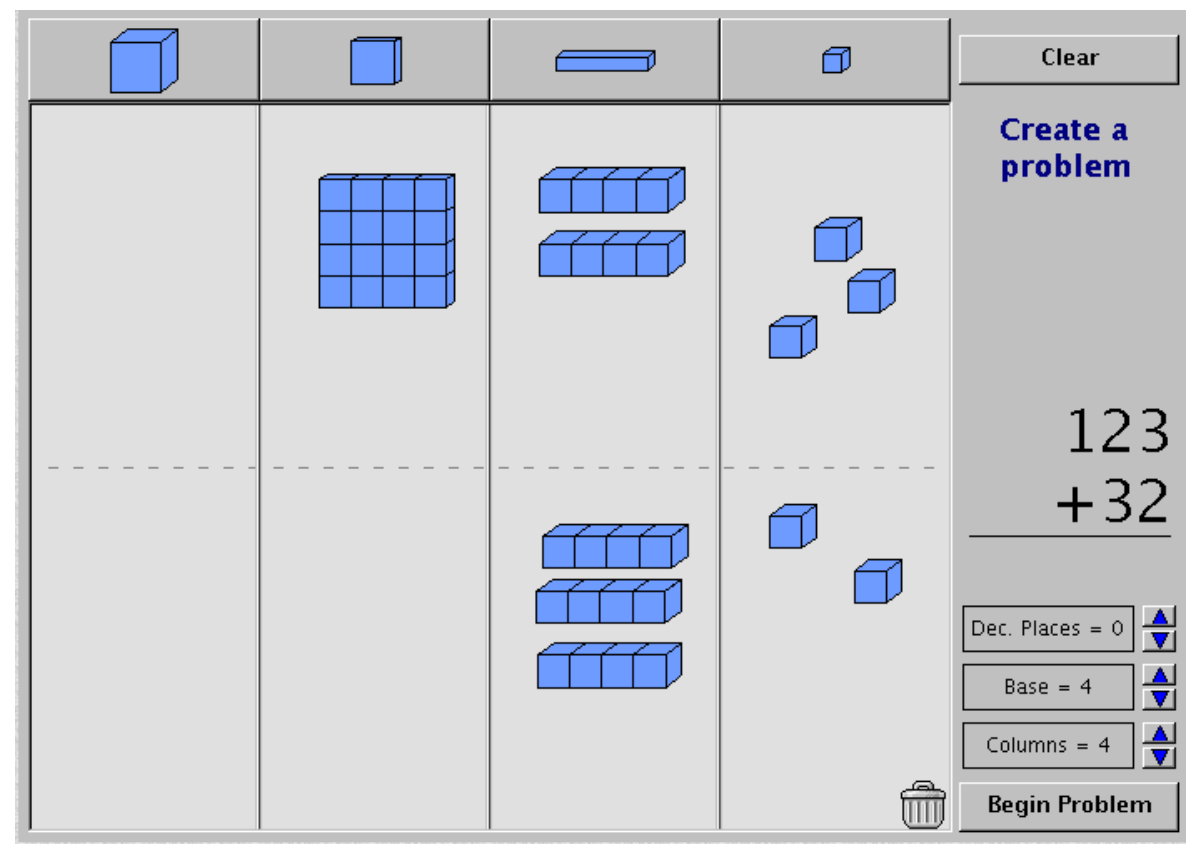

1. Explore this applet, and complete the addition problem that applet shows using base blocks. Click the next problem button to obtain a new exercise and do it.

2. Click the create problem button. Could you represent and solve the followings additions using this applet?
a) $1321_{\text {(four }}+232_{\text {(four }}$
b) $2121_{\text {(four }}+1213_{\text {(four }}$
c) $4331_{\text {(five }}+242_{\text {(five }}$
d) $1821_{\text {(ten }}+8292_{\text {(ten }}$

General description of the exercise

This exercise aims to developing mental images of numbers, place value, and operations, and it is also useful in illustrating the grouping rules. In addition, students could explore and describe the rule that determines place value.

It is very important that students realize that rule of addition in different base systems is the same, the only change is in the number of things that make up one group. Representing addition in other than the base 10 number system reinforces the rules of grouping.

All these activities could improve the number sense of students, because algorithms and properties of numbers are important aspect in arithmetic. 


\section{Evaluation of the adaptation and conclusions}

After the planning and experimentation in the course Mathematics and its pedagogy, we not only fulfilled the guidelines for avancing in the adaption of the course to the future EHEA but recognized several issues that we consider very valuable, both in our professional development as trainers involved in the project and in the development of the area of knowledge in the Faculty of Education and at the University of Granada.

First, the experience promoted interesting debates and discussions among the professors related to the planning of teacher training in the area of mathematics. These activities led us to generate classroom materials agreed upon by the professors and tested with the students. Second, the described actions generated significant changes in the students' attitude toward the course Mathematics and its pedagogy and to school math. Their participation in the activities, the stimulus to work autonomously, and the fostering of communication among students and between students and professors constitutes one of the great advances in this experience. Further, we have established a work model for classrooms with a large number of students (over 100) where it is difficult a priori to abandon a methodology based on the lecture class.

This experience is important to adapt instruction to the new European directives in the material of higher education as evidenced by the interest in this experience shown in diverse forums (Flores, Segovia and Lupiáñez, 2006; Flores, Segovia, Lupiáñez and Molina, 2007; Lupiáñez, Segovia and Flores, 2006; Segovia, Flores, Lupiáñez and Molina, 2007). We have also been invited to help other Spanish universities (Flores and Segovia, 2006), and our work has become the subject of a chapter in a book on the European convergence (Segovia, Lupiáñez and Flores, 2006).

Recently we have initiated an evaluation of the practice part of the program of this course which aims to study its potential as element of development of mathematical professional competences for prospective teachers (Cecilia, 2007). This analysis is based on the list of professional mathematical competences for teachers enclosed in Appendix A.

Cecilia has examined the quantity of activities which promote the development of each competence and the weight that each competence plays in the prospective teachers' evaluation 
processes. These processes are explicited in the team workbook that students must complete after the practical classess.

Till the moment just the part of the practice program related to the content of arithmetic and to the laboratory scenario has been analysed. This analysis has shown that this part of the program is coherent and mainly promotes the development of competences related to knowledge and understanding of mathematical contents and to teaching materials and resources. The competences related to actitude towards mathematics are less present. We are still working on the evaluation of the rest of the program. 


\section{References}

Beneitone, P., Esquetini C., González, J., Maletá, M.M., Siufi G. y Wagenaar, R. (2007). Final Report ALFA Tuning America Latina Project: Reflections on and outlook for Higher Education in Latin America. Bilbao: University of Deusto and University of Groningen. Available at http://tuning.unideusto.org/tuningal/index.php?option=com docman\&Itemid= $191 \&$ task $=$ view category\&catid $=22 \&$ order $=$ dmdate $\_$published\&ascdesc $=$DESC

Caamaño, A. (2003). Los trabajos prácticos en ciencias. In M.P. Jiménez, A. Caamaño, A. Oñorbe, E. Pedrinaci and A. de Pro, Enseñar ciencias (pp. 95-118). Barcelona: Editorial Graó.

Cecilia, L.M. (2007). Estudio de un programa de prácticas de matemáticas para maestros. Trabajo de Investigación Tutelada. Departamento de Didáctica de la Matemática, Universidad de Granada.

Díaz-Godino, J. (2005). Aplicación de un enfoque pragmático sobre las competencias y la cognición al desarrollo curricular. Unpublished document. Granada: Mathematics Education Department.

Ferrater, J. (1991). Diccionario de Filosofia. Madrid: Alianza.

Flores, P. and Segovia, I. (Eds.) (2004). Prácticas de matemáticas para maestros. Granada: Mathematics Education Department.

Flores, P. and Segovia, I. (2006). Adaptación de los créditos prácticos. Presented in the course titled Los títulos de Educación en el Marco Europeo de Educación Superior. Salamanca: March 2006.

Flores, P., Segovia, I. and Lupiáñez, J.L. (2006). Matemáticas y su Didáctica en el marco del EEES. Presented in Jornadas de Trabajo sobre Experiencias Pilotos de Implantación del Crédito Europeo en las Universidades Andaluzas. Cádiz: September 19-21, 2006.

Flores, P., Segovia, I. Lupiáñez, J.L. and Molina, M. (2007). Innovación en la formación matemática de maestros. Presented in Jornadas de innovación docente universitaria en el marco del EEES. Granada: June 18-19, 2007.

Llinares, S. (1998). Conocimiento profesional del profesor de matemáticas y procesos de formación. UNO, 17, 51-65. 
Lupiáñez, J.L. Segovia, I. and Flores, P. (2006). Formación Inicial de Profesores de Primaria en Matemáticas en el Marco del Espacio Europeo de Educación Superior: Implicaciones para el Aprendizaje de los Escolares. In J.I. Navarro and M. Aguilar (Eds.), Learning Maths in childhood. Proceedings of the International Symposium on Early Mathematics (pp. 307-328). Cádiz: Departamento de Psicología de la Universidad de Cádiz.

Monereo, C. (1994). Estrategias de enseñanza y aprendizaje. Barcelona: Graó.

Moral, C. (2001). Actividades prácticas en el aprendizaje universitario. In Moral, C. (Coord.), Guía III Materiales de formación del profesor universitario. Proyecto andaluz de formación del profesorado universitario (pp. 303-333). Sevilla: UCUA.

Pollard, A. (1997). Reflective teaching and competence. En A. Pollard, Reflective Teaching in the Primary School. London, Casell pp. 3-28;

Pozo, J.I. and Monereo, C. (1999). El aprendizaje estratégico. Madrid: Santillana.

Resnick, L. B., \& Ford, W. W. (1981). The psychology of mathematics for instruction. Hillsdale, NJ: Lawrence Erlbaum.

Reys, R. E., Rybolt, J. F., Bestgen, B. J. y Wyatt, J. W. (1980). Identification and characterization of computational estimation processes used by in-schools pupils and out-ofschool adults. Final Report, National Institute of Education, Grant No. 79-0088.

Rico, L. (Coord.) (1997). La educación matemática en la enseñanza secundaria. Barcelona: Horsori.

Segovia, I., Flores, P., Lupiáñez, J.L. and Molina, M. (2007). Planificación de las asignaturas de Educación Matemática para maestros en el marco del EEES. Presented in II jornadas de Innovación docente: Innovar para el ECTS. Granada: May 8, 15, 22 and June $1,2007$.

Segovia, I., Lupiáñez, J.L. and Flores, P. (2006). Formación práctica en educación matemática del profesor de primaria para la Europa del siglo XXI. In J.L. Benítez, J. de la Fuente, A.B. Berbén and F. Justicia, La universidad ante el reto del espacio europeo de educación superior: investigaciones recientes (pp. 177-208). Madrid: Editorial EOS.

Sowder, J. (1992). Estimation and Number Sense. En D. A. Grouws (Ed.), Handbook of research on mathematics teaching and learning (pp. 371-389). NY: Macmillan Publishing Company and NCTM. 
Vizcarro, C., Liébana, C., Hernández, A., Juárez, E. and Izquierdo, F. (1999). Evaluación de estrategias de aprendizaje. In J.I. Pozo and C. Monereo (Coord.), El aprendizaje estratégico. Enseñar a aprender desde el currículo (pp. 277-299). Madrid: Aula XXI Santillana.

\section{Acknowledgements}

This work was partially supported by the project SEJ2005-07364/EDUC of the Spanish Ministry of Education and Science and the project SEJ2006-09056 of the Spanish Ministry of Sciences and Technology, including FEDER funds. The authors belong to the Spanish research group FQM “Didáctica de la Matemática: Pensamiento Numérico (FQM-193)” from the andalusian plan of Research, Development and Innovation. 


\section{Appendix A: Unified list of professional mathematical competences for teachers}

One of the most important innovations involved in the future curricula adapted to the European Higher Education Area (EHEA) is the planning of the objectives as professional competences to be achieved. The list of competences for the area of mathematics is the following one (we include the Tuning competences list):

\section{Specific Mathematics competences}

\section{1: (To know to)}

1.1.1. To know and understand the mathematics contents of Primary School Curriculum 1.1.2. To know and understand foundations and history of mathematics of didactic interest in relation to the Primary School Curriculum

1.1.3. To know and understand the social and cultural role of mathematical contents of the Primary School Curriculum

\section{2: (To know how) \\ In relation to Primary Education levels: Problem solving}

1.2.1. To identify and classify problems according to different types

1.2.2. To formulate problems associated with different contexts and situations

1.2.3. To solve mathematical problems using different strategies

1.2.4. To verify and interpret results of the problems

1.2.5. To generalize the solutions of the problems

1.2.6. To apply mathematical knowledge to practical situations

\section{Representation}

1.2.7. To use the processes of mathematical symbolization and representation (verbal, numerical, symbolic, geometric, graphical...).

1.2.8. To translate from one into another kind of representation

\section{Communication}

1.2.9. To coherently communicate basic mathematics in a spoken and written way

1.2.10. To understand, to interpret and to judge mathematical ideas presented in a written, oral or visual way

\section{Conceptual domain}

1.2.11. To identify and generate examples of concepts in different contexts and situations

1.2.12. To recognize the various meanings and interpretations of the concepts

1.2.13. To recognize and define concepts and their properties

1.2.14. To recognize the relational elements of a conceptual structure

\section{Procedural domain}

1.2.15. To recognize when a procedure is suitable

1.2.16. To explain the different steps of a procedure

1.2.17. To put into practice a procedure in a reliable and efficient way

1.2.18. To generate new procedures and extend or modify those already known

1.2.19. To implement methods and techniques related to Mathematics in an accurate way 


\section{Justification}

1.2.20. To provide arguments to justify answers to mathematical questions and procedures 1.2.21. To use the various ways of mathematical reasoning (inductive, proportional, spatial and deductive) to justify properties and procedures

\section{Use of materials and resources}

1.2.22. To show skill in using materials and resources for elementary mathematics, including ICT (Information and Communication Technologies)

\section{3: (To know to behave)}

1.3.1. To have a positive disposition and attitude toward mathematics, valuing it social and cultural role

1.3.2. To recognize the role of mathematics as a language, as a tool for solving problems and as a tool for modelling the reality

\section{Professional competences to teach Mathematics in Primary School}

\section{1: (To know to)}

2.1.1. To know and to evaluate critically theoretical foundations of the Mathematics Education, applied to primary education levels, with regard to the following four dimensions:

a) Educational perspective of mathematics;

b) Principles of teaching and learning of mathematics;

c) Mathematical curriculum in primary education;

d) Technological resources and manipulative materials

2.1.2. To know media, materials and resources usual in the teaching and learning of mathematics, including ICT

2.1.3. To know and to assess critically the contributions of Mathematics Education to the teaching and learning of mathematical contents and processes addressed in primary education, and referred to curricular guidelines, stages of learning, kind of errors and difficulties, assessment tools, experienced proposals of education, etc.

2.1.4. To know about the different forms of organization of a classroom that can be used in mathematics, recognizing the specificities of the area of mathematics

\section{2. (To Know how)}

2.2.1. To know and interpret the professionals curricular documents, especially the official ones related to Mathematics

2.2.2. To design didactic sequences appropriated to the level of elementary education by applying the available didactic skills in a critical and reflective way

2.2.3. To design interdisciplinary activities of mathematics with other areas of the curriculum 2.2.4. To have available strategies to manage a mathematics classroom, knowing the interactive aspects involved in it, providing motivation and allowing an adequate treatment of the students' diversity

2.2.5. To know and to be able to apply assessment strategies, applying the available didactic knowledge in a critical and reflective way 


\section{3: (To know to behave)}

2.3.1. To have a positive attitude towards the mathematics teaching, appreciating its formative role and its utility in compulsory education

\section{Professional competences (interdisciplinary)}

\section{1: General competences of the prospective teacher of primary education}

3.1.1. To reflect on professional development through mathematical school practice

3.1.2. To use research, proposal and problem-solving strategies both in school and non-school situations

3.1.3. To be able to reflect on the teaching-learning process

3.1.4. To interpret the difficulties and problems of the teaching profession and to take appropriate decisions for their solution

3.1.5. To critically analyze the information to be useful to act as a teacher

3.1.6. To be able to learn autonomously in order to facilitate their professional update in a future

3.1.7. To research into their own practice, introducing innovation proposals aimed at improving and generating new ideas

\section{2: Competences related to classroom}

\section{Planning}

3.2.1. To plan the courses in the social context in which they will be taken by making appropriate decisions regarding selection of aims, organization of contents, design of activities or evaluation criteria

\section{Communication}

3.2.1. To present what is taught by using a clear language and in a stimulating way

3.2.2. To promote discussion in the classroom effectively through participating and supporting the discussion

\section{Methodology}

3.2.3. To use a variety of teaching strategies that are appropriate to the topic as well as to the students in the classroom

3.2.4. To adopt active, participatory and creative methodologies, developing the curriculum starting from situations which are significant for the students, assuming a role as a counsellor, facilitator and guide of learning, as well as looking to motivate and make students interested in learning

3.2.5. To identify occasions in which is advisable for teaching to work with the classroom as a whole group, as small groups, in couples or individually

3.2.6. To consider and deal with cultural differences among students

3.2.7. To encourage and stimulate students to take initiatives and to take responsibility in their own learning

3.2.8. To harmonize and integrate educational theory and practice

3.2.9. To assess their teaching activity

3.2.10. To describe and justify the methodology used 


\section{Guidance of the classroom}

3.2.11. To display a certain variety of approaches to create and keep an order and a good learning atmosphere

3.2.12. To channel students' behaviour through the appropriate use of rewards and penalties, and to be aware of when it is necessary to seek advice

3.2.13. To keep students' interest and motivation under their responsibility

3.2.14. To assess their actions in the class guidance

\section{Assessment}

3.2.15. To know and to use the principles of assessment and the different kind of assessment that can be used

3.2.16. To describe and to assess how students acquire new knowledge

3.2.17. To assess and to consider the students 'individual progress in a systematic way

3.2.18. To provide a regular feedback to pupils on their progress

3.2.19. To assess, to evaluate and to improve their teaching

\subsection{Competences related to school}

3.3.1. To know the system in which they are working and specially the organization and direction of schools or the school policies to use in order to develop and advance their teaching 3.3.2. To deal with parents about their children's learning progress

3.3.3. To establish relationships with colleagues of profession from the same school and from other educational centres

3.3.4. To know and find the aid resources and experts of use at certain times

3.3.5. To deal with crucial aspects of the school curriculum and to consider them in the most suitable way

3.3.6. To contribute to activities with students outside the formal curriculum

3.3.7. To guide and to mentor students at the personal, academic and vocational scope by mean of their leadership skills

3.3.8. To participate in the transformation of the institutional culture of schools and other educational fields where they are involved by proposing alternative dynamics for teaching

\subsection{Competences and attitudes related to professionalism}

\subsubsection{To know all legal aspects related to their profession}

3.4.2. To describe and to assess their professional career

3.4.3. Commitment to work and to those people connected through work

3.4.4. Commitment to control and continue their professional development

3.4.5. Commitment to collaborate with others and to promote the students' achievement

3.4.6. Commitment to promote ethical attitudes in their pupils

3.4.7. Commitment to the community where the school is immersed

3.4.8. Commitment to multicultural and non-discrimination policies acceptance

\section{Transversal or interdisciplinary competences}

The general competences to be developed in the teaching and learning university processes are classified into three categories: instrumental, interpersonal and systemic (Tuning Project). In each category there are the following types:

4.1. Instrumental competences (tools for learning and training):

4.1.1. Capacity for analysis and synthesis

4.1.2. Capacity to organize and to plan

4.1.3. Basic general knowledge in the field of study 
4.1.4. Basic knowledge of the profession in practice

4.1.5. Oral and written communication in their native language

4.1.6. Knowledge of a second language

4.1.7. Elementary computing skills

4.1.8. Management of information skills

4.1.9. Problem solving

4.1.10. Decision-making

4.2. Interpersonal competences (capabilities that ensure a good working and personal relationship with third party)

4.2.1. Critical and self-critical abilities

4.2.2. Teamwork

4.2.3. Interpersonal skills

4.2.4. Ability to work in an interdisciplinary team

4.2.5. Ability to communicate with experts of other areas

4.2.6. Appreciation of diversity and multiculturality

4.2.7. Ability to work in an international context

4.2.8. Ethical commitment

4.3. Systemic competences (capabilities which provide an overview and are suitable to manage the whole performance):

4.3.1. Capacity for applying knowledge in practice

4.3.2. Research skills

4.3.3. Capacity to learn

4.3.4. Capacity to adapt to new situations

4.3.5. Capacity for generating new ideas (creativity)

4.3.6. Leadership

4.3.7. Understanding of cultures and customs of other countries

4.3.8. Ability to work autonomously

4.3.9. Project design and management

4.3.10. Initiative and entrepreneurial spirit

4.3.11. Concern for quality

4.3.12. Will to succeed

Appendix B. Work guide for the professor and students in the first topic of the course Mathematics and its Pedagogy

\section{MATHEMATICS EDUCATION DEPARTMENT. UNIVERSITY OF GRANADA}

Course: Mathematics and its pedagogy. Degree: Teacher in Primary Education. Academic year 2004-05

Guide to Topic 1: NATURAL NUMBER. NUMBER SYSTEMS.

1.Uses of natural numbers (1, pp. 123ff.).

2.Concept of natural number (1, pp. 128ff.).

3.Ordering. The sequence of counting numbers (1, pp. 131-132). Quantifying. Strategies. The zero (1, pp. 133ff) \& (2, pp. 31).

4.Representation of the number. Number systems: antecedents and their evolution (1, pp. $138 \mathrm{ff}) \&(2$, pp. 31). 
5.Place value numeric systems. Decimal Number System (1, pp. 140) \& (2, pp. 55).

6.Materials and resources (1, pp. 141) \& (2, pp. 163).

\section{Bibliography}

(1) Castro, E. (Ed.) (2001). Didáctica de la matemática en la Educación Primaria. Síntesis: Madrid.

(2) Gómez, B. (1988). Numeración y cálculo. Síntesis: Madrid.

(3) Nortes, A. (1995). Matemáticas y su didáctica. Lerco Print: Madrid

\section{Orientations for the students' work}

There are three basic ideas associated with this chapter: the idea of the natural number, which is extracted from reflection on the mathematical concept, its use and its forms of representation. Relative to this concept, we hope that students will develop an idea of the significance of the concept of number from its ordinal and cardinal conceptions. As to its use, students should grasp the importance of understanding the sequence of counting numbers as well as know the basic principles of the activity of counting and the strategies that are employed in the fundamental uses of the number: ordering and quantifying. Concerning the forms of representing numbers, students should master the principles of functioning of the decimal number system and other forms of representation that enable reflection and analysis of it (e.g. about the presence of the zero, place value, etc.). Finally, students should know some of the most common materials and resources in the teaching and learning of numbers and the number system, such as Cuisenaire rods, multibase blocks and the abacus. We propose activities that involve the questions that students should be able to answer. We also present some examples that can serve for reflection while also illustrating whether students understand the theoretical questions and knows how to apply them.

\section{Activities for reflection and evaluation}

- What is a number? When is it employed (used)?

- What is counting / pairing? What kind of number results from counting/pairing? How is the number that results from counting characterized? How does one count?

- What is ordering? What kind of number results from ordering? How is the number that results from ordering characterized?

- What are the ways to represent the number? What are the characteristics of the written decimal number system? And of the oral system?

- How is the Roman numeral system different to the decimal number system?

- What other systems share any characteristics with the decimal number system?

- What are the particular qualities of the zero? What function does the sign of zero have in the decimal number system?

- What educative materials can be used to work on the learning of the decimal number system? How is each of these materials used? 